\title{
Interleukin 1 Gene Expression in Adult T Cell Leukemia
}

\author{
Yuji Wano," Toshio Hattori, ${ }^{\ddagger}$ Masao Matsuoka, ${ }^{\ddagger}$ Kiyoshi Takatsuki, ${ }^{*}$ Anne O. Chua, ${ }^{5}$ Ueli Gubler, ${ }^{\mathbf{3}}$ and Warner C. Greene* \\ *Howard Hughes Medical Institute, Department of Medicine, Duke University School of Medicine, Durham, North Carolina 27710; \\ ${ }^{\ddagger}$ Second Department of Medicine, Kumamoto University Medical School, Kumamoto 860, Japan; and $\$$ Department of Molecular \\ Genetics, Hoffmann-La Roche, Inc., Nutley, New Jersey 07110
}

\begin{abstract}
The adult $T$ cell leukemia (ATL) is a $T$ cell neoplasm etiologically associated with human $T$ lymphotropic virus type $I$ (HTLV-I) infection. ATL cells often abnormally express interleukin 2 (IL-2) receptors, and ATL patients may show clinical evidence of hypercalcemia, osteolytic bone lesions, or increased bone turnover. Whereas interleukin 1 (IL-1) is not generally recognized as a product of $T$ cells, this cytokine is capable of both altering IL-2 receptor expression and activating osteoclasts. Thus, we investigated the possibility that primary ATL leukemic T cells and HTLV-I-infected long-term ATL cell lines produce IL-1. S1 nuclease protection assays demonstrated that primary leukemic ATL cells from five out of six patients, as well as one patient with $\mathrm{T}^{+}$chronic lymphocytic leukemia, contained considerable quantities of IL-1 $\beta$ messenger RNA (mRNA) and small amounts of IL-1 $\alpha$ mRNA. These primary leukemic $T$ cells also released biologically active IL-1 protein as evaluated in the murine thymocyte comitogenesis bioassay. In contrast to primary tumor cells, four out of six long-term ATL cell lines produced variable amounts of IL-1 $\alpha$ mRNA in the absence of detectable IL-1 $\beta$ mRNA as measured by S1 nuclease protection. These data demonstrate that IL-1 gene (especially IL-1 $\beta$ ) expression occurs in many primary HTLV-I-infected leukemic $T$ cells raising the possibility that this mediator may play a role in the pathological changes associated with this leukemia. Also, these studies show that the pattern of IL-1 $\alpha$ and IL-1 $\beta$ gene expression differs between primary ATL tumor cells and long-term cultured ATL cell lines, indicating an interesting biological difference in these two HTLV-I-infected cell populations.
\end{abstract}

Part of this study was presented at the annual meeting of Federation of American Society for Experimental Biology, Washington D. C., March-April 1987, and was published as an abstract (Fed. Proc. 46:1344.).

Address all correspondence to Dr. Y. Wano, Howard Hughes Medical Institute, Duke University Medical Center, P. O. Box 3705, Durham, NC 27710.

Received for publication 21 January 1987 and in revised form 20 April 1987.

J. Clin. Invest.

(c) The American Society for Clinical Investigation, Inc.

0021-9738/87/09/0911/06 \$2.00

Volume 80, September 1987, 911-916

\section{Introduction}

The adult $T$ cell leukemia (ATL) ${ }^{1}$ is a usually fatal $T$ cell malignancy produced by human $\mathrm{T}$ lymphotropic virus type $\mathrm{I}$ (HTLV-I) infection of $\mathrm{T}^{+}$and $\mathrm{T}^{+}$lymphocytes (helper/inducer phenotype) (1-3). These leukemic $T$ cells are often characterized by the abnormal constitutive expression of membrane receptors for interleukin 2 (IL-2) $(4,5)$. Clinically, this leukemia may present in acute, chronic, or smoldering forms (6). The acute form of this disease, and the development of a leukemic crisis in the other less common forms, is frequently associated with hypercalcemia (6-8), evidence of increased bone turnover or osteolysis. Several investigators have reported that HTLV-I-infected primary leukemic T cells produce osteoclast-activating factor (OAF) or OAF-like substance(s) that promote bone resorption and may contribute to the development of hypercalcemia (8-12). However, this ATL-associated OAF has not been purified and remains poorly characterized. Recently, Dewhirst et al. (13) purified a human OAF $\left(M_{\mathrm{r}}\right.$ of 17,800 ; isoelectric point [pI]6.8) from mitogen and phorbol ester-activated peripheral blood mononuclear cells (PBMC) and unexpectedly found that its $\mathrm{NH}_{2}-$ terminal amino acid sequence was identical to that of interleukin $1 \beta(\operatorname{IL}-1 \beta)(14,15)$. This finding, coupled with the recognized ability of IL-1 to induce IL-2 receptor gene expression $(16,17)$ and to enhance bone resorption in vitro $(18,19)$, prompted us to investigate whether primary ATL tumor cells and HTLV-I-infected long-term ATL cell lines produce IL-1.

\section{Methods}

Patients. Seven patients with HTLV-I-induced ATL and one patient with $\mathrm{T4}^{+}$chronic lymphocytic leukemia (CLL) not associated with HTLV-I infection were studied. All the ATL cases, but not the $\mathrm{T4}^{+}$ CLL case, were found to contain a monoclonal pattern of HTLV-I provirus integration in the tumor cell DNA (2). All but one of the ATL cases represented patients with the acute form of leukemia. The other ATL patient (case 5) had high leukemic cell counts in the peripheral blood $(34,000-50,100 / \mu 1)$, but was clinically stable without treatment, and thus was categorized as "chronic" ATL.

Cells. The long-term cultured HTLV-I-infected T cell lines

1. Abbreviations used in this paper: ATL, adult T cell leukemia; CLL, chronic lymphocytic leukemia; HTLV-I, human T lymphotropic virus type I; nt, nucleotides; OAF, osteoclast-activating factor; PBMC, peripheral blood mononuclear cells; rIL- $\alpha$ and rIL- $1 \beta$, recombinant interleukin $1 \alpha$ and $1 \beta$. 
HUT-102B2, MT-1, MJ, C5/MJ, PLP6, and C91/PL (20-22) were cultured in complete medium consisting of RPMI 1640 supplemented with $10 \%$ heat inactivated fetal calf serum (FCS), $2.0 \mathrm{mM} \mathrm{L}$-glutamine, $100 \mathrm{U} / \mathrm{ml}$ penicillin and $100 \mu \mathrm{g} / \mathrm{ml}$ streptomycin. PBMC from normal volunteers and the leukemic patients were separated by Ficoll-Hypaque density gradient centrifugation. PBMC populations from the leukemic patients consisted of $\geq 92 \%$ of $\mathrm{T}^{1} 1^{+}$cells, $\geq 76 \%$ of $\mathrm{T}^{+}$cells, and $<2 \%\left(<1 \%\right.$ in most cases) of $\mathrm{Mol}^{+}$cells as assessed by flow cytofluorometry, which indicate minimal monocyte contamination. Cells from the buffy coats of normal donors were cultured for $18 \mathrm{~h}$ in the presence of lipopolysaccharide (LPS, $10 \mu \mathrm{g} / \mathrm{ml}$ ).

IL-1 complementary DNA (cDNA) and protein. The human IL-1 $\alpha$ (23) and IL-1 $\beta$ (14) cDNAs used have been previously described. Purified recombinant IL- $1 \alpha$ (rIL-1 $\alpha)$ and IL-1 $\beta$ (rIL-1 $\beta$ ) were kindly provided by the Otsuka Pharmaceutical Co. (Tokushima, Japan) and the Dainippon Pharmaceutical Co. (Osaka, Japan), respectively.

Murine thymocyte proliferation assay for IL-1 activity. Supernatants from cultures of the ATL, T4 ${ }^{+}$CLL, or normal cells $\left(10^{6} / \mathrm{ml}\right)$ were harvested after $72 \mathrm{~h}$ of incubation in complete medium. After sterile filtering, serial dilutions of these supernatants were added to $\mathrm{C} 3 \mathrm{H} / \mathrm{HeN}$ murine thymocytes cultured in complete medium in the presence of $5 \mu \mathrm{g} / \mathrm{ml}$ of PHA (Difco, Inc., Findlay, $\mathrm{OH}$ ), as previously described (24). $\left[{ }^{3} \mathrm{H}\right]$ Thymidine was added during the final $6 \mathrm{~h}$ of the 72-h culture.

S1 nuclease protection assay of leukemic $T$ cell RNA. RNA was purified by the guanidine isothiocyanate method (25). $10 \mu \mathrm{g}$ of total RNA obtained from the different leukemic and normal cell populations were hybridized with either the IL- $1 \alpha$ or IL- $1 \beta$ cDNAs and digested with $\mathrm{S} 1$ nuclease, as previously described (26). In this assay, fully spliced IL- $1 \alpha$ messenger RNA (mRNA) protects a 210 -nucleotide (nt) fragment (amino acids 64-134 of the IL-1 $\alpha$ precursor protein) derived from exons 4 and 5 (27). IL- $1 \beta$ mRNA protects a 525-nt fragment (amino acids 133-269 of the IL-1 $\beta$ precursor plus $116 \mathrm{nt}$ from the $3^{\prime}$ untranslated region). The specific activity of the end-labeled probes used was $1 \times 10^{4}-2 \times 10^{4} \mathrm{dpm} / \mathrm{fmol}$.

\section{Results}

Primary ATL tumor cells contain $I L-1 \alpha$ and $I L-1 \beta m R N A$. To investigate the possibility of IL-1 gene expression in the primary leukemia $\mathrm{T}$ cell populations, $\mathrm{S} 1$ nuclease protection assays were performed with total RNA isolated from these neoplastic cells. As shown in Fig. 1 (left), the expected 210-nt fragment protected by IL- $1 \alpha$ mRNA was readily detected in the LPS-induced buffy coat cell RNA (positive control), but not in the pig gut RNA sample (negative control) nor in the absence of added RNA. Large quantities of IL- $1 \alpha$ mRNA were present in the $\mathrm{T} 4{ }^{+}$CLL RNA sample, whereas very low, but detectable, levels of IL- $1 \alpha$ mRNA were present in RNA isolated from ATL cases, 1, 2, 3, and 4. IL- $1 \alpha$ mRNA was not detected in ATL cases 5 and 6 nor in RNA isolated from the HTLV-I-infected HUT-102B2 cell line. RNA from the induced human peripheral blood leukocytes (buffy coat cells) consistently yielded two protected fragments, 210 and $125 \mathrm{nt}$ in length $(26,27)$. This finding is explained by the fact that this S1 probe includes sequences from both exons 4 and 5 of the IL-1 $\alpha$ gene $(27,28)$. The 210 -nt fragment is produced after hybridization of the probe to fully spliced or mature IL-1 $\alpha$ mRNA, whereas the 125-nt fragment, by hybridization of the probe to unspliced IL-1 $\alpha$ mRNA. The 3' 85-nt fragment was not detected in our procedure as a $5^{\prime}$ end-labeled fragment was used. The difference in relative ratio of the 210 - and 125-nt fragments between the $\mathrm{T} 4^{+}$CLL and the buffy coat cell samples, thus, may reflect a difference in relative amounts of spliced and unspliced IL- $1 \alpha$ mRNA present in these two different cell populations.

Much greater quantities of IL- $1 \beta$ mRNA were detected in five out of six ATL cases (cases 1-4 and 6) as indicated by the intensities of the protected 525-nt fragments (right, Fig. 1). ATL case 5 was the only leukemic sample that did not contain either IL- $1 \alpha$ or IL- $1 \beta$ mRNA. Interestingly, these cells were obtained from a patient with a chronic rather than acute form of this leukemia. The $\mathrm{T}^{+} \mathrm{CLL}$ cells contained large quantities of IL-1 $\beta$ mRNA, whereas HUT-102B2 T cells again lacked this mRNA species. Buffy coat RNA, pig gut RNA, and no RNA controls yielded the appropriate patterns of protection. The multiple smaller bands observed in the IL- $1 \beta$ assay reflect partial escape from complete protection that is commonly observed with this particular probe and the conditions of S1 nuclease digestion used.

These findings indicate that many of the primary ATL tumor cells express both IL- $\alpha$ and IL- $1 \beta$ mRNA and that the levels of IL- $1 \beta$ mRNA are considerably greater than those of IL-1 $\alpha$ mRNA. Northern blotting studies confirmed the presence of IL- $1 \beta$ mRNA in four out of six ATL leukemias and in the $\mathrm{T}^{+}$CLL sample. However, using this less sensitive technique, IL- $1 \alpha$ mRNA production was weakly detected in the $\mathrm{T4}^{+}$CLL RNA sample only and undetectable in all of the ATL samples (data not shown).

Thymocyte comitogenic activity in culture supernatants of primary tumor $T$ cells. To examine whether these tumor $\mathrm{T}$ cells actually release biologically active IL-1 protein, the cells were cultured for $72 \mathrm{~h}$ in complete medium and the culture supernatants assayed for the presence of thymocyte comitogenic activity. As summarized in Table I, a control supernatant obtained from normal PBMC did not promote significant $\left[{ }^{3} \mathrm{H}\right]$ thymidine incorporation by murine thymocytes, whereas both purified recombinant IL- $1 \alpha$ and IL- $1 \beta$ significantly enhanced thymoctye proliferation in a dose-dependent manner. Supernatants from the $\mathrm{T4}^{+}$CLL and four of the ATL cases that contained IL-1 mRNA, as well as an additional ATL sample not studied at the RNA level (case 7), contained IL-1 biological activity as measured in this assay. These results suggest that the primary tumor cells from the ATL and T4 ${ }^{+} \mathrm{CLL}$ patients secrete or release biologically active IL-1 protein.

The absence of IL-IB MRNA in HTLV-I-infected longterm cell lines. Whereas IL-1 gene expression was evident in most of the HTLV-I-infected primary ATL cells, the HTLVI-infected long-term ATL line, HUT-102B2, did not appear to contain either IL- $\alpha$ or IL-1 $\beta$ mRNA (Fig. 1). To determine whether this was a general property of long-term cultured ATL cell lines, RNA samples from five additional ATL cell lines were studied for the presence of IL- $1 \alpha$ or IL- $1 \beta$ mRNA. IL- $1 \beta$ gene expression was undetectable in all of the ATL cell lines (right, Fig. 2). In contrast, considerable quantities of IL-1 $\alpha$ mRNA were present in the C91/PL and C5/MJ RNA samples, whereas small amounts were detected in the PLP6 and MJ cell lines. No IL- $1 \alpha$ mRNA was found in the HUT-102B2 or MT-1 RNA samples. Thus, these findings suggest that the pattern of IL-1 gene expression differs in primary and long-term cultured cell lines infected with HTLV-I.

\section{Discussion}

These studies demonstrate that IL-1 gene expression occurs in freshly isolated primary tumor cells from many ATL patients 


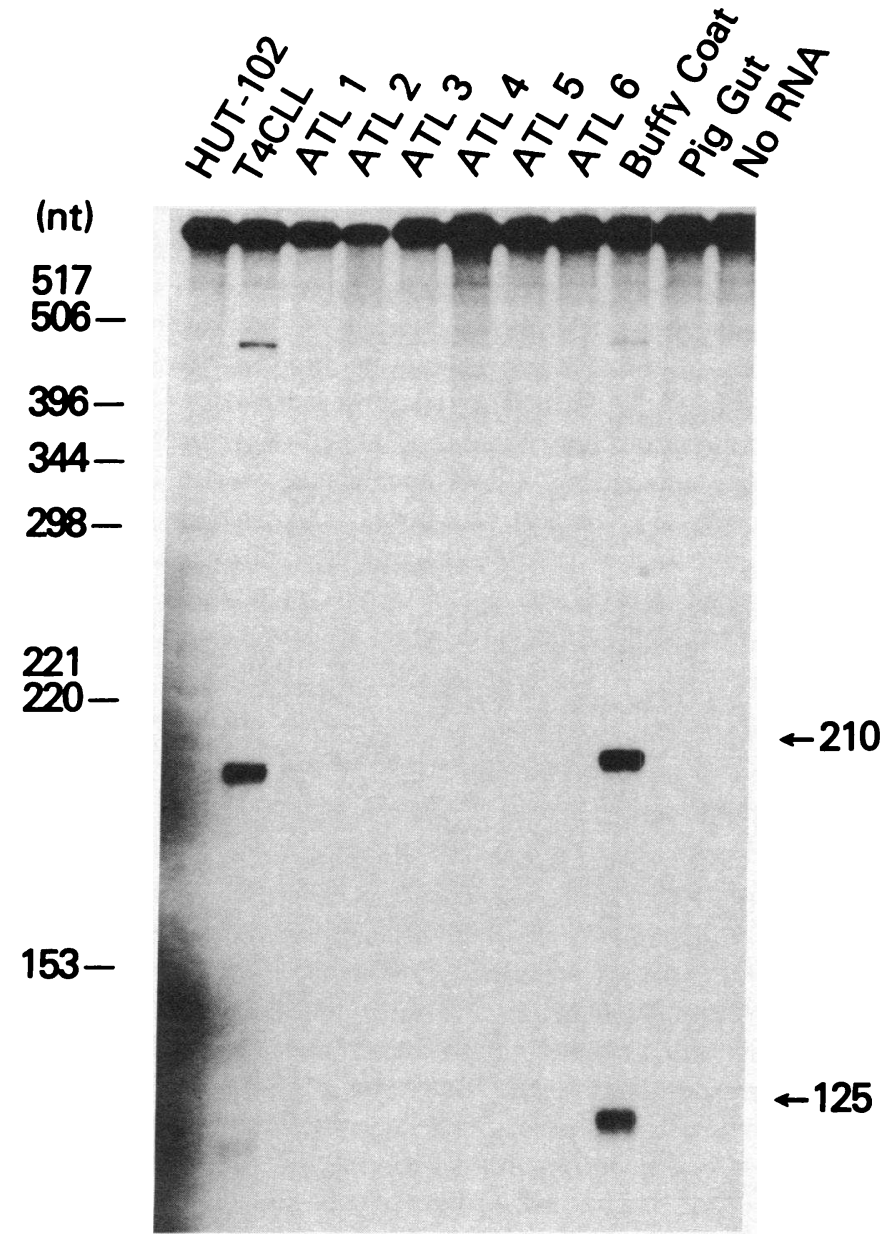

\section{$\mathrm{IL}-1 a$}

Figure 1. S1 nuclease protection assay of RNA isolated from primary leukemic $\mathrm{T}$ cells. End-labeled cDNA probes specific for IL-1 $\alpha$ (left) and IL-1 $\beta$ (right) mRNA were hybridized with $10 \mu \mathrm{g}$ of total RNA from the normal and primary leukemic cells followed by digestion with S1 nuclease (26). As a positive and a negative control, RNA was

as well as in a single case of $\mathrm{T} 4^{+} \mathrm{CLL}$. It is unlikely that these IL-1 mRNAs are derived from contaminating monocytes since, in most cases, the $\mathrm{Mol}^{+}$cells represented $<1 \%$ (at most $<2 \%$ ) of the tumor cell population and no specific macrophage-inducing agents were used. Furthermore, identically prepared normal T cell populations and one ATL sample containing a similar number of $\mathrm{Mol}^{+}$cells lacked detectable evidence of IL-1 gene expression. In all populations of the positive primary ATL tumor cells studied, the relative amounts of IL- $1 \beta$ mRNA were far greater than that of IL- $1 \alpha$ mRNA. Also, these cells secreted biologically active IL-1 protein as measured in the murine thymocyte costimulator assay. In sharp contrast, none of the six HTLV-I-infected long-term cultured ATL cell lines contained IL- $1 \beta$ mRNA; however, four of these cell lines produced variable amounts of IL- $1 \alpha$ mRNA. These findings reveal an intriguing difference in these two HTLV-I-infected cell populuations. Interestingly, recent studies have suggested that many long-term cultured ATL cell lines do not corre-
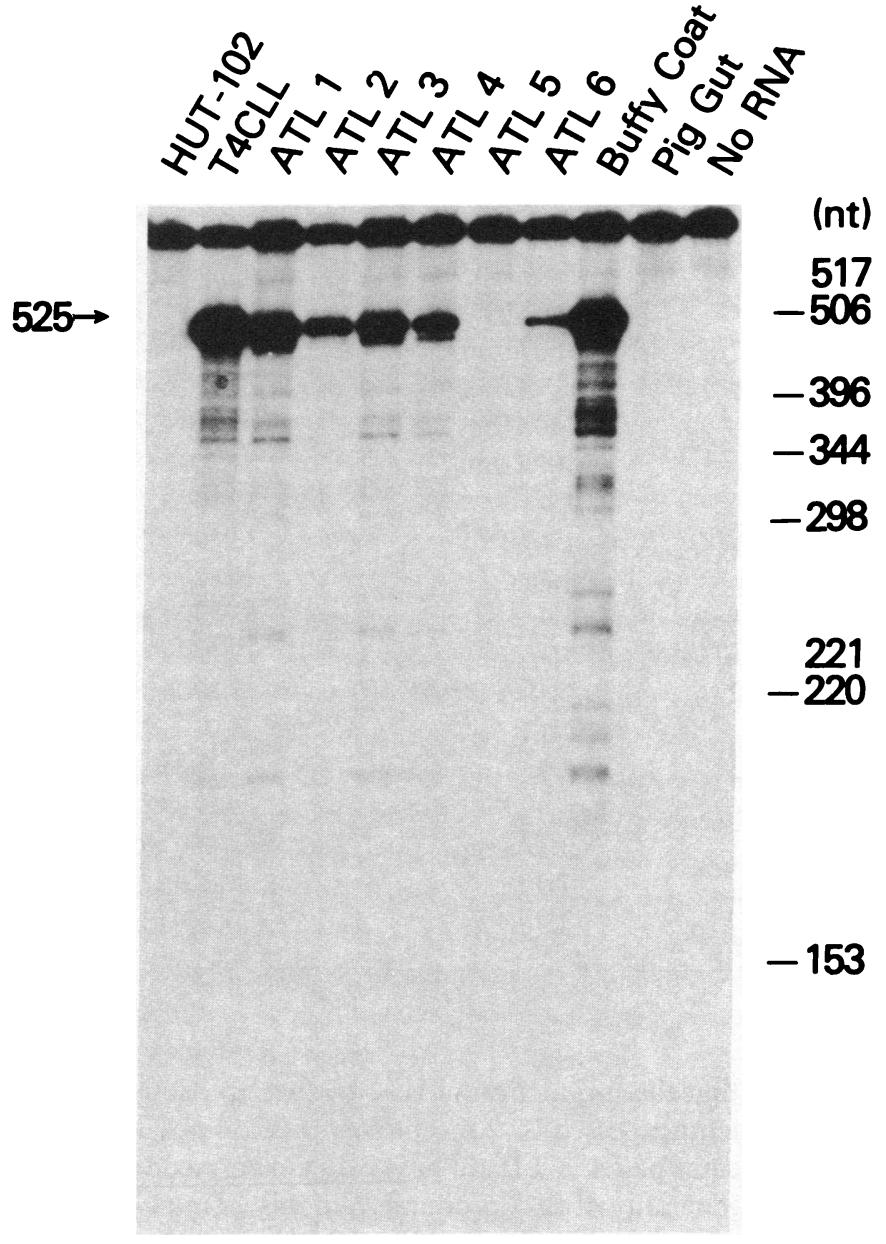

IL-1 $\beta$

isolated from LPS-stimulated peripheral blood leukocytes (buffy coat) and pig gut, respectively. $\mathrm{S} 1$ nuclease digestion of each probe in the absence of added RNA was also performed. The digestion products were size-fractionated on a $5 \%$ denaturing acrylamide sequencing gel, and exposed to Kodak XAR film for $55 \mathrm{~h}$ at $-70^{\circ} \mathrm{C}$.

spond to the original primary tumor cells based on the clonal pattern of rearrangements within the $T$ cell receptor $\beta$ chain gene locus or in the integration site of the HTLV-I provirus (29). Also, expression of the transactivator (tat) gene product of HTLV-I is usually undetectable in uncultured primary leukemia cells, whereas long-term cultured ATL cell lines often contain relatively large quantities of this protein (30). Furthermore, the primary leukemic T cells often require IL-2 for short-term growth, whereas the ATL cell lines generally proliferate readily in the absence of IL-2. Thus, it is clear that these two HTLV-I-infected T cell populations exhibit potentially important genetic and functional differences.

Marked IL-1 production was also observed in the single case of $\mathrm{T}^{+}$CLL studied. These cells do not contain integrated HTLV-I provirus, thus, IL-1 production by leukemic T cells does not appear to be solely limited to HTLV-I-infected cells. Interestingly, these $\mathrm{T}^{+}$cells also display IL-2 receptors and respond to exogenous IL-2 with increased proliferation. It is 
Table I. Thymocyte Comitogenic Activity in the Tumor Cell Culture Supernatants

\begin{tabular}{llc}
\hline Experiments & $\begin{array}{l}\text { Final dilution } \\
\text { or concentration }\end{array}$ & ['H]TdR incorporation \\
\hline & & mean $\pm S D$ cpm \\
Medium & $1: 4$ & $650 \pm 100$ \\
rIL-1 $\alpha$ & $10 \mathrm{U} / \mathrm{ml}$ & $8,400 \pm 850$ \\
rIL-1 $\beta$ & $100 \mathrm{U} / \mathrm{ml}$ & $26,650 \pm 880$ \\
& $1 \mathrm{U} / \mathrm{ml}$ & $3,710 \pm 120$ \\
& $10 \mathrm{U} / \mathrm{ml}$ & $14,910 \pm 2,610$ \\
T4 CLL & $100 \mathrm{U} / \mathrm{ml}$ & $27,760 \pm 5,470$ \\
& $1: 4$ & $31,100 \pm 2,210$ \\
& $1: 12$ & $23,800 \pm 1,510$ \\
ATL case 1 & $1: 36$ & $9,620 \pm 570$ \\
& $1: 4$ & $32,250 \pm 6,710$ \\
ATL case 2 & $1: 12$ & $19,250 \pm 1,450$ \\
& $1: 4$ & $8,370 \pm 2,880$ \\
ATL case 3 & $1: 12$ & $1,050 \pm 190$ \\
ATL case 6 & $1: 4$ & $3,250 \pm 1,790$ \\
& $1: 4$ & $4,620 \pm 820$ \\
& $1: 12$ & $2,840 \pm 990$ \\
ATL case 7 & $1: 36$ & $1,220 \pm 230$ \\
& $1: 4$ & $20,200 \pm 1,440$ \\
\hline
\end{tabular}

possible that the production of IL-1 by these cells may play a role in the unexpected IL-2 receptor expression observed. Additional cases of $\mathrm{T}^{+} \mathrm{CLL}$ are now being examined to investigate the generality of IL-1 production in this form of leukemia and to determine the relationship of this mediator to the abnormal expression of IL-2 receptors.

Whereas IL-1 gene expression has been previously demonstrated in a variety of cell types, including monocytes-macrophages, B cells, and endothelial cells (31), T cell production of this cytokine has not been generally recognized. Recently, Tartakovsky and colleagues (32) have reported IL- $1 \alpha$ production by certain antigen-specific murine $T$ cell clones after activation with antigen-presenting $B$ cells. Noma and colleagues (33) also have described IL- $1 \alpha$ but not IL- $1 \beta$ mRNA production in a few long-term cultured human $T$ cell lines infected with HTLV-I. Our finding of the IL- $1 \alpha$ and IL- $1 \beta$ gene expression in primary ATL and T4 ${ }^{+}$CLL cells coupled with the finding that four out of six HTLV-I-infected long-term $T$ cell lines expressed the IL- $1 \alpha$ gene provides additional evidence that IL-1 gene expression can occur in activated cells of the T lymphocyte lineage.

Although IL-1 production by primary ATL tumor cells appears to represent very common finding (thymocyte comitogenic activity has also been detected in the leukemic cells isolated from eight out of nine additional ATL cases not discussed in this paper), it is unclear what role this mediator plays in the pathological changes associated with this leukemia. IL-1 has been reported to enhance IL-2 receptor expression $(16,17$, 31 ), and abnormal IL-2 receptor display is a common feature in $\operatorname{ATL}(4,5)$. Whereas it is possible that IL-1 production plays a direct role in altering IL-2 receptor gene expression, our preliminary results indicate that neutralizing anti-rIL- $1 \alpha$ or anti-rIL- $1 \beta$ rabbit heteroantibodies fail to inhibit the sponta- neous increase in IL-2 receptor expression that occurs when primary ATL tumor cells are placed in short-term culture (3). Furthermore, in contrast to a previous report (34), we have been unable to demonstrate that rIL- $1 \alpha$ or rIL-1 $\beta$ enhances either IL-2 receptor display or the proliferation of freshly isolated ATL cells. Moreover, we did not detect IL-1 $\alpha$ or IL-1 $\beta$ gene expression in HTLV-I-infected HUT-102B2 or MT-1 cells that constitutively express large numbers of IL-2 receptors. Thus, while not completely excluded, a causal role for IL- $1 \alpha$ or IL- $1 \beta$ in the abnormal expression of IL- 2 receptors in HTLV-I-induced ATL has not been established.

A second prominent feature of HTLV-I-induced ATL is its frequent association with hypercalcemia (6-12). The common findings of osteoclast activation on bone biopsy and increased bone turnover without evidence of frank tumor cell infiltration $(8,10-12)$ has suggested the possible involvement of circulating humoral factor(s) in ATL-associated hypercalcemia. The abnormal production of such humoral factors as parathyroid hormone, $1,12-(\mathrm{OH})_{2}$ vitamin $\mathrm{D}_{3}$, or prostaglandins, implicated as the cause of hypercalcemia in other malignancies (35), has not been detected in ATL (8-12). Our findings of IL-1 production by primary ATL tumor cells coupled with previous reports of OAF production by these cells (8-12) is particularly intriguing in view of the report by Dewhirst et al. (13) that OAF and IL- $1 \beta$ are identical in size, isoelectric point, functional properties (thymocyte comitogenesis and bone resorption), and $\mathrm{NH}_{2}$-terminal amino acid sequence. It seems likely that at least one OAF produced by primary ATL tumor cells corresponds to IL- $1 \beta$.

In this regard, hypercalcemia was documented at the time of tumor cell isolation in two of the ATL patients studied (cases 1 and 2). The lack of hypercalcemia in the other cases may reflect compensatory changes in renal and endocrine function, which serve to normalize the level of serum calcium (35). Consistent with this possibility, Bunn et al. (8) have noted that ATL patients often show evidence of osteoclast activation and accelerated bone turnover in the absence of frank hypercalcemia. Neither bone biopsies nor metabolic bone turnover studies were available from the present group of patients. Thus, to establish firmly the possible relationship of IL- $1 \alpha$ and IL- $1 \beta$ production to ATL-associated changes in calcium metabolism, serial prospective studies correlating IL-1 production with changes in bone turnover, osteoclast activation, and serum and urine calcium levels will be required.

IL-1 can also produce neutrophilia, acute inflammatory protein secretion by hepatocytes, and fever in vivo $(31,36)$. In this regard, Yamamoto et al. (37) have described the frequent presence of neutrophilia in ATL patients. It is possible that ATL cell-derived IL-1 may mediate this response. Also, ATL patients, including those we have studied, often exhibit elevated serum levels of lactic dehydrogenase, alkaline phosphatase, and C-reactive protein $(1,6,8)$. These changes may be consistent with a role for IL-1; however, direct leukemic cell infiltration of the liver (a frequent finding in ATL) could also produce these changes $(1,8)$. Finally, fever is a frequent clinical finding in ATL; however, it is difficult to implicate tumor cell-derived IL-1 as its sole cause given the frequency of intercurrent opportunistic infections and the administration of multiple drugs.

Of note, the single ATL case (case 5) whose tumor cells did not contain either IL- $1 \alpha$ or IL-1 $\beta$ mRNA was clinically diag- 


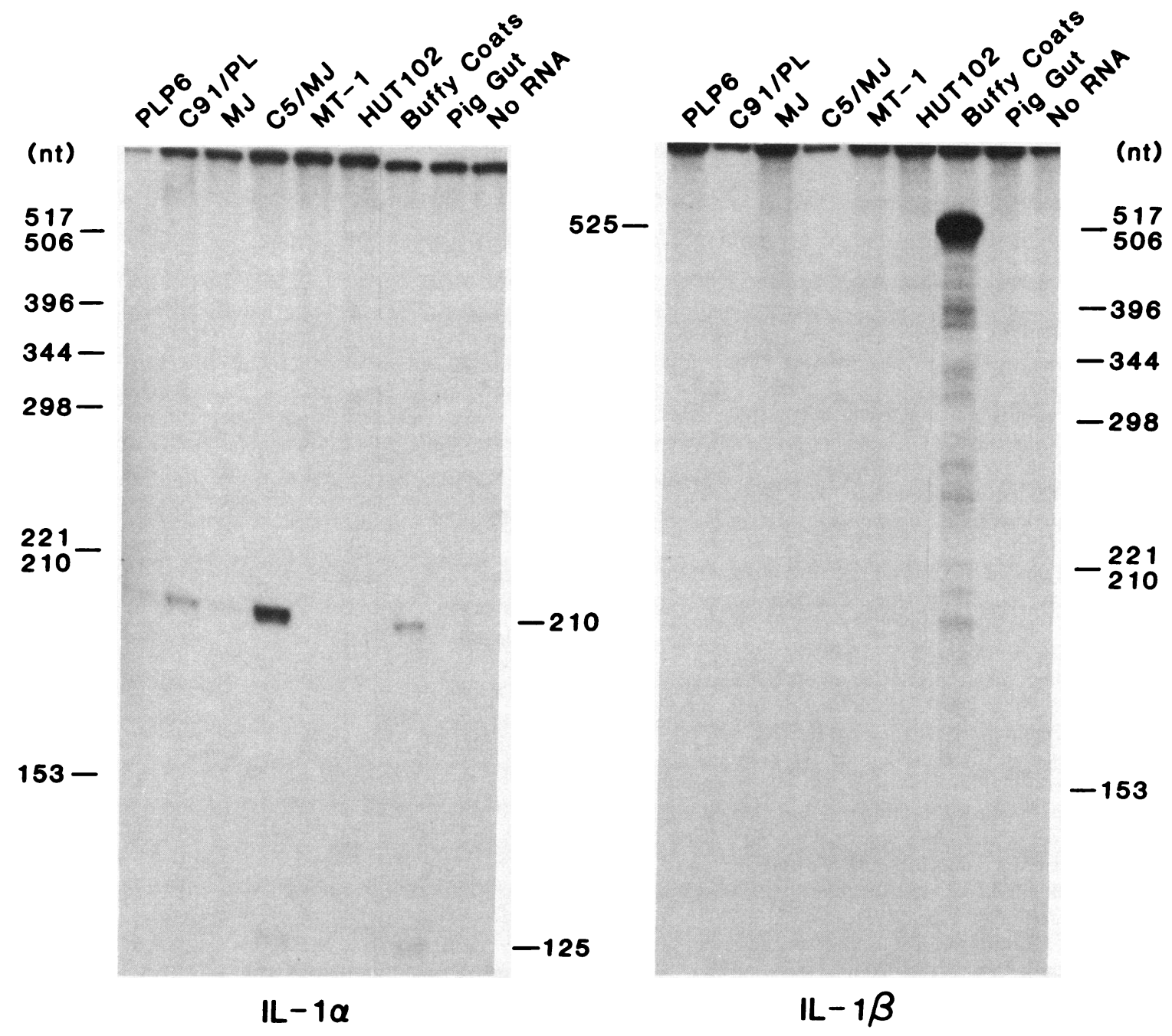

Figure 2. S1 nuclease protection assay of RNA from long-term cultured ATL (HTLV-I infected) cell lines. For details, see the legend for Fig. 1. Left, IL-1 $\alpha$; right, IL-1 $\beta$.

nosed as chronic ATL. Preliminary studies of leukemic cells from a second chronic ATL case also has revealed a lack of IL-1 mRNA production. Further studies of the potential differences in IL-1 gene expression in the acute vs. chronic or smoldering forms of ATL are presently underway.

\section{Acknowledgments}

We wish to thank Dr. I. Miyoshi of Kochi Medical School, Japan for a generous gift of MT-1 cell line.

This work was partially supported by a grant in aid for scientific research from the Ministry of Education, Science, and Culture, Japan.

\section{References}

1. Uchiyama, T., J. Yodoi, K. Sagawa, K. Takatsuki, and H. Uchino. 1977. Adult T-cell leukemia: clinical and hematologic features of 16 cases. Blood. 50:481-492.

2. Yoshida, M., M. Seiki, K. Yamaguchi, and K. Takatsuki. 1984. Monoclonal integration of human T-cell leukemia provirus in all primary tumors of adult T-cell leukemia suggests causative role of human
T-cell leukemia virus in the disease. Proc. Natl. Acad. Sci. USA. 81:2534-2537.

3. Hattori, T., T. Uchiyama, T. Toibana, K. Takatsuki, and H. Uchino. 1981. Surface phenotype of Japanese ATL cells characterized by monoclonal antibodies. Blood. 58:645-647.

4. Tsudo, M., T. Uchiyama, H. Uchino, and J. Yodoi. 1983. Failure of regulation of Tac antigen/TCGF receptor on adult T cell leukemia cells by anti-Tac monoclonal antibody. Blood. 61:1014-1016.

5. Krönke, M., W. J. Leonard, J. M. Depper, and W. C. Greene. 1985. Deregulation of interleukin-2 receptor gene expression in HTLV-I-induced adult T-cell leukemia. Science (Wash. DC). 228:1215-1217.

6. Yamaguchi, K., H. Nishimura, F. Kawano, H. Kohrogi, M. Jono, Y. Miyamoto and K. Takatsuki. 1983. A proposal for smoldering adult $\mathrm{T}$-cell leukemia-diversity in clinical pictures of adult $\mathrm{T}$-cell leukemia. Jpn. J. Clin. Oncol. 13(Suppl. 2):189-200.

7. Catovsky, D., M. F. Greaves, M. Rose, D. A. G. Galton, A. W. G. Goolden, D. R. McCluskey, J. M. White, I. Lampert, G. Bourikas, R. Ireland, A. I. Brownell, J. M. Bridges, W. A. Blattner, and R. C. Gallo. 1982. Adult T-cell lymphoma-leukemia in Blacks from the West Indies. Lancet. 1:639-643.

8. Bunn, P. A., G. P. Schechter, E. Jaffe, D. Blayney, R. C. Young, J. J. Matthews, W. Blattner, S. Broder, M. Robert-Guroff, and R. C. 
Gallo. 1983. Clinical course of retrovirus-associated adult T-cell lymphoma in the United States. N. Engl. J. Med. 309:257-264.

9. Grossman, B., G. P. Schechter, J. E. Horton, L. Pierce, E. Jaffe, and L. Wahl. 1981. Hypercalcemia associated with T-cell lymphomaleukemia. Am. J. Clin. Pathol. 75:149-155.

10. Brigham, B. A., P. A. Bunn, J. E. Horton, G. P. Schechter, L. M. Wahl, E. C. Bradley, R. Dunnick, and M. J. Matthews. 1982. Skeletal manifestations in cutaneous T-cell lymphomas. Arch. Dermatol. 118:461-467.

11. Blayney, D. W., E. S. Jaffe, R. I. Fisher, G. P. Schechter, J. Cossman, M. Robert-Guroff, V. S. Kalyanaraman, W. A. Blattner, and R. C. Gallo. 1982. The human T-cell leukemia/lymphoma virus, lymphoma, lytic bone lesions and hypercalcemia. Ann. Intern. Med. 98:144-151.

12. Fujihira, T., S. Eto, K. Sato, K. Zeki, S. Oda, S. Chiba, and H. Suzuki. Evidence of bone resorption-stimulating factor in adult T-cell leukemia. Jpn. J. Clin. Oncol. 15:385-391.

13. Dewhirst, F. E., P. P. Stashenko, J. E. Mole, and T. Tsurumachi. 1985. Purification and partial sequence of human osteoclast-activating factor: identity with interleukin $1 \beta$. J. Immunol. 135:25622568.

14. Auron, P. E., A. C. Webb, L. J. Rosenwasser, S. F. Mucci, A. Rich, S. M. Wolff, and C. A. Dinarello. 1984. Nucleotide sequence of human monocyte interleukin-1 precursor cDNA. Proc. Natl. Acad. Sci. USA. 81:7907-7911.

15. March, C. J., B. K. Moslay, A. Larsen, D. P. Cerretti, G. Braedt, V. Price, S. Gillis, C. S. Henney, S. R. Kronheim, K. Grabstein, P. F. Conlon, T. P. Hopp, and D. Cossman. 1985. Cloning, sequence and expression of two distinct human interleukin-1 complementary DNAs. Nature (Lond.). 315:641-647.

16. Kaye, J., S. Gillis, S. B. Mizel, E. M. Shevach, T. R. Malek, C. A. Dinarello, L. B. Lachman, and C. A. Janeway. 1984. Growth of a cloned helper $\mathrm{T}$ cell line induced by a monoclonal antibody specific for the antigen receptor: interleukin 1 is required for the expression of receptors for interleukin 2. J. Immunol. 133:1339-1345.

17. Lowenthal, J. W., J.-C. Cerottini, and H. R. MacDonald. 1986. Interleukin 1-dependent induction of both interleukin 2 secretion and interleukin 2 receptor expression by thymoma cells. J. Immunol. 137:1226-1231.

18. Gowen, M., D. D. Wood, E. J. Ihrie, M. K. B. McGuire, and R. G. G. Russell. 1983. An interleukin 1 like factor stimulates bone resorption in vitro. Nature (Lond.). 306:378-380.

19. Heath, J. K., J. Saklatvala, M. C. Meikle, S. J. Atkinson, and J. J. Reynolds. 1985. Pig interleukin 1 (catabolin) is a potent stimulator of bone resorption in vitro. Calcif. Tissue Int. 37:95-97.

20. Gazdar, A. F., D. N. Carney, P. A. Bunn, E. K. Russell, E. S. Jaffe, G. P. Schechter, and J. G. Guccion. 1980. Mitogen requirements for the in vitro propagation of cutaneous T-cell lymphomas. Blood. 55:409-417.

21. Miyoshi, I., I. Kubonishi, M. Sumida, S. Yoshimoto, S. Hiraki, T. Tsubota, H. Kobashi, M. Lai, T. Tanaka, I. Kimura, K. Miyamoto, and J. Sato. 1979. Characteristics of a leukemic T-cell line derived from adult T-cell leukemia. Jpn. J. Clin. Oncol. 9:485-494.

22. Popovic, M., P. S. Sarin, M. Robert-Gurroff, V. S. Kalyanaraman, D. Mann, J. Minowada, and R. C. Gallo. Isolation and transmission of human retrovirus (human T-cell leukemia virus). Science (Wash. DC). 219:856-859.
23. Gubler, U., A. O. Chua, A. S. Stern, C. P. Hellmann, M. P. Vitek, T. M. Dechiara, W. R. Benjamin, K. J. Collier, M. Dukovich, P. C. Familletti, C. Fiedler-Nagy, J. Jenson, K. Kaffka, P. L. Killian, D. Stremlo, B. H. Wittreich, D. Woehle, S. B. Mizel, and P. T. Lomedico. 1986. Recombinant human interleukin $1 \alpha$ : purification and biological characterization. J. Immunol. 136:2492-2497.

24. Mizel, S. B., J. J. Oppenheim, and D. L. Rosenstreich. 1978. Characterization of lymphocyte activating factor (LAF) produced by the macrophage cell line, $\mathrm{P}_{388 \mathrm{D}_{1}}$. I. Enhancement of LAF production by activated T lymphocytes. J. Immunol. 120:1497-1503.

25. Chirgwin, J. M., A. E. Przybyla, R. J. McDonald, and W. J. Rutter. 1979. Isolation of biologically active ribonucleic acid from sources enriched in ribonuclease. Biochemistry. 18:5294-5299.

26. Kupper, T. S., D. W. Ballard, A. O. Chua, J. S. McGuire, P. M. Flood, M. C. Horowitz, R. Langdon, L. Lightfoot, and U. Gubler. 1986. Human keratinocytes contain mRNA indistinguishable from monocyte interleukin $1 \alpha$ and $\beta$ mRNA. J. Exp. Med. 164:2095-2100.

27. Le, J., D. Weinstein, U. Gubler, and J. Vilček. 1987. Induction of membrane-associated interleukin 1 by tumor necrosis factor in human fibroblasts. J. Immunol. 138:2137-2142.

28. Furutani, Y., M. Notake, T. Fukui, M. Ohue, H. Normura, M. Yamada, and S. Nakamura. 1986. Complete nucleotide sequence of the gene for human interleukin 1 alpha. Nucleic Acids Res. 14:31673179.

29. Maeda, M., A. Shimizu, K. Ikuta, H. Okamoto, M. Kashihara, T. Uchiyama, T. Honjo, and J. Yodoi. 1985. Origin of human T-lymphotrophic virus I-positive T cell lines in adult T cell leukemia. J. Exp. Med. 162:2169-2174.

30. Franchini, G., F. Wong-Staal, and R. C. Gallo. 1984. Human T-cell leukemia virus (HTLV-I) transcripts in fresh and cultured cells of patients with adult T-cell leukemia. Proc. Natl. Acad. Sci. USA. 81:6207-6211.

31. Oppenheim, J. J., E. J. Kovacs, K. Matsushima, S. K. Durum. 1986. There is more than one interleukin 1. Immunol. Today. 7:45-56.

32. Tartakovsky, B., E. J. Kovacs, L. Takacs, and S. K. Durum. 1986. T cell clone producing an IL-1-like activity after stimulation by antigen-presenting B cells. J. Immunol. 137:160-166.

33. Noma, T., T. Nakamura, M. Maeda, M. Okada, Y. Taniguchi, Y. Tagaya, Y. Yaoita, J. Yodoi, and T. Honjo. 1986. Interleukin la mRNA in virus-transformed T and B cells. Biochem. Biophys. Res. Commun. 139:353-360.

34. Shirakawa, F., Y. Tanaka, S. Oda, S. Chiba, H. Suzuki, S. Eto, and Y. Yamashita. 1986. Effect of interleukin 1 on the proliferation and the expression of interleukin 2 receptors of adult $T$ cell leukemia cells in vitro. Proc. Jpn. Cancer Assoc. 45:208. (Abstr.)

35. Mundy, G. R., K. J. Ibbotson, and S. M. D'Souza. 1985. Tumor products and the hypercalcemia of malignancy. J. Clin. Invest. 76:391-394.

36. Auron, P. E., S. J. C. Warner, A. C. Webb, J. G. Cannon, H. A. Bernheim, K. J. P. W. McAdam, L. J. Rosenwasser, G. LoPreste, S. F. Mucci, and C. A. Dinarello. 1987. Studies on the molecular nature of human interleukin 1. J. Immunol. 138:1447-1456.

37. Yamamoto, S., T. Hattori, N. Asou, H. Nishimura, F. Kawano, J. Yodoi, and K. Takatsuki. 1986. Absolute neutrophilia in adult T cell leukemia. Jpn. J. Cancer Res. (Gann). 77:858-861. 